\title{
A Framework for Socioeconomic Valuation of Biodiversity in the PABITRA Focal Sites in Fiji ${ }^{1}$
}

\begin{abstract}
Isoa Korovulavula ${ }^{2}$
Abstract: In Fiji, one of the underlying causes of historical and current losses of biodiversity has been lack of recognition of the value of many biological resources. The Pacific-Asia Biodiversity Transect (PABITRA) project provides an opportunity for integration of social and economic valuation of biodiversity. This is critical for any decision relating to management and conservation of biodiversity resources. Socioeconomic valuation of biodiversity can assist communities and policy makers to better understand the net benefits of managing and conserving biodiversity. This paper presents a framework that can be applied for valuing the socioeconomic attributes of biodiversity in the PABITRA focal sites. This framework has two components. First is the quantitative method of valuation. For this, environmental economics can be applied, in particular the use of nonmarket valuation methods. Second is the qualitative method. This is based on application of participatory economic valuation methods. This second method of eliciting economic values incorporates institutional, social, and cultural activities and equity issues at the village or community levels.
\end{abstract}

"VALUE IS a pluralistic concept: it is possible to speak of biological resources possessing intrinsic value dependent of humankind, ecological value, economic value, cultural and spiritual value, evolutionary value and so on" (Moran and Pearce 1999:89). The focus of my paper is economic value, a concept limited to anthropogenic values only. In addition there are two dimensions to economic value: a qualitative one, which provides an understanding of the importance of biodiversity resources to the productive and reproductive activities of different groups within a community at different stages of their lives and in different seasons; and one that provides quan-

1 This paper was presented at the 20th Pacific Science Congress held in Bangkok in 2003 with funding from the Asia-Pacific Network for Global Change Research/ Pacific-Asia Biodiversity Transect project. Manuscript accepted 23 April 2004.

${ }^{2}$ Fellow, Environment Unit, Institute of Applied Sciences, University of the South Pacific, Suva, Fiji.

Pacific Science (2005), vol. 59, no. 2:205-211

(C) 2005 by University of Hawai'i Press

All rights reserved titative summaries of key aspects of these activities.

Socioeconomic values are directly linked to stakeholders. For example in the focal sites of Wabu, Waisoi, Sovi, and Savura the tropical forest ecosystem is relatively intact. An environmental organization concerned with tropical deforestation in terms of area (hectares) destroyed and area protected from destruction would be more interested in the value per hectare than would a landowner in the area who has a farm. The landowner would be more interested in the higher value return per hour of labor expended for slash and burn. As Gregersen et al. (1995:6) put it, "the question is: who makes the decisions and, thus, whose point of view is relevant?" Different people are concerned with different measures of production, depending on their individual circumstances.

In the Pacific-Asia Biodiversity Transect (PABITRA) Fiji focal sites there are three main stakeholders: the landowners, the State, and the tenants, who are basically farmers. These stakeholders value natural resources differently. One of the key areas of study in this proposed socioeconomic valuation framework is to elicit and synthesize the val- 
ues that these stakeholders have so that a meaningful social and economic analysis can be applied to provide a good grounding for any future conservation work.

In this paper I propose two complementary economic valuation approaches that may be able to capture the economic, social, cultural, spiritual, and institutional aspects of biodiversity. First is the application of environmental economics: specifically, the use of relevant and practical nonmarket valuation techniques. This is a quantitative approach of eliciting monetary values. The second approach is participatory economic valuation, in which participatory research or rural appraisal tools are used. This is qualitative in nature.

QUANTITATIVE APPROACH: APPLICATION OF ENVIRONMENTAL ECONOMICS

Environmental economics includes the valuation of nonmarket benefits. This is important for the comparison of land uses with different environmental impacts. It encourages the analyst to consider the full opportunity costs of changes in land use. One of the challenges in the valuation of biodiversity and natural resources is the general lack of reliable data on the stock and flow of resources (e.g., forest products) and biological growth rates. It is important to have correct and reliable information on the flow and stock of resources (Richards and Davies 1999). Therefore it is important that the concept of flow and stock is understood clearly. Tietenberg (2000:37) explained that: "depending upon the circumstance, we may need to place a value on either a stock or a flow. For example, the standing forest is a stock of trees, while the harvest of timber from that forest represents the service flows. The two are connected in that the value of a stock should be equal to the present value of the stream of services flowing from the stock."

There are basically three main components of values in environmental economics (Moran and Pearce 1999, Tietenberg 2000). They are (1) use value; (2) option value; and (3) nonuse value.

Use values refer to the direct and indirect use of environmental resources. Direct use values include things such as the gathering of nontimber forest products or harvesting timber from the forest or water extracted from a stream. Indirect use values include regulatory services that ecosystems provide (Campbell and Brown 2003). For example, intact wetlands have an assimilative and cleaning capacity to absorb and purify water, thus providing human societies with clean water.

The term option value refers to the value that people place on their ability to use the environment in the future. For example, the opportunity to develop an agricultural area at some stage in the future may be seen as an option value if we assume that most other ecosystem services will continue to function.

Nonuse values comprise existence and bequest values (Richards and Davies 1999, Campbell and Brown 2003). The existence value is the value placed on the continued existence of something independent of its use value (Richards and Davies 1999). For example, there is a large concern for the plight of blue whales in the world, although most people will never see or use them (Moran and Pearce 1999). Bequest value is the value one places on the environmental good for ones' descendants. According to Richards and Davies (1999:17) bequest value "is a special case of option value: it represents the value (to current users) of being able to bequeath the forest to future generations." Therefore, total economic value (TEV) can be mathematically illustrated as: $\mathrm{TEV}=$ use value (indirect and direct use) + option value + nonuse value (existence and bequest values). Furthermore these values can be identified and in some cases standardized in monetary terms by using nonmarket valuation techniques.

\section{Nonmarket Valuation Methods}

As summarized in Table 1, there are three nonmarket valuation approaches: the production approach, the expenditure approach, and the utility approach (Barbier et al. 1998, Campbell and Brown 2003).

THE PRODUCTION APPROACH. "The production approach estimates value by trying to 
TABLE 1

Three Approaches to Nonmarket Economic Valuation

\begin{tabular}{|c|c|c|}
\hline Nonmarket Valuation Methods & Description & PABITRA Site \\
\hline \multicolumn{3}{|l|}{ Production approach } \\
\hline Change in productivity & $\begin{array}{l}\text { Examines changes in the dollar value of outputs } \\
\text { resulting from the change of environmental goods }\end{array}$ & Waibau \\
\hline Opportunity cost method & $\begin{array}{l}\text { This is applied to measure the benefits foregone by not } \\
\text { using the resource }\end{array}$ & \\
\hline \multicolumn{3}{|l|}{ Expenditure approach } \\
\hline Preventive expenditure method & $\begin{array}{l}\text { Examines expenditures made to mitigate the effects of } \\
\text { decreased environmental quality (e.g., biodiversity } \\
\text { conservation and management expenditure) }\end{array}$ & \\
\hline Mitigation cost method & $\begin{array}{l}\text { Uses estimates of the cost of repair or rehabilitation of } \\
\text { environmental resources after environmental damage }\end{array}$ & Monasavu \\
\hline \multicolumn{3}{|l|}{ Utility approach } \\
\hline Contingent valuation method & Uses survey techniques to directly elicit people's & Sovi \\
\hline & willingness to pay or to accept compensation for & Waisoi \\
\hline & different qualities of an environmental good or service & Savura \\
\hline & & Nasoata \\
\hline
\end{tabular}

Note: Adapted from Campbell and Brown (2003) and Barbier et al. (1998).

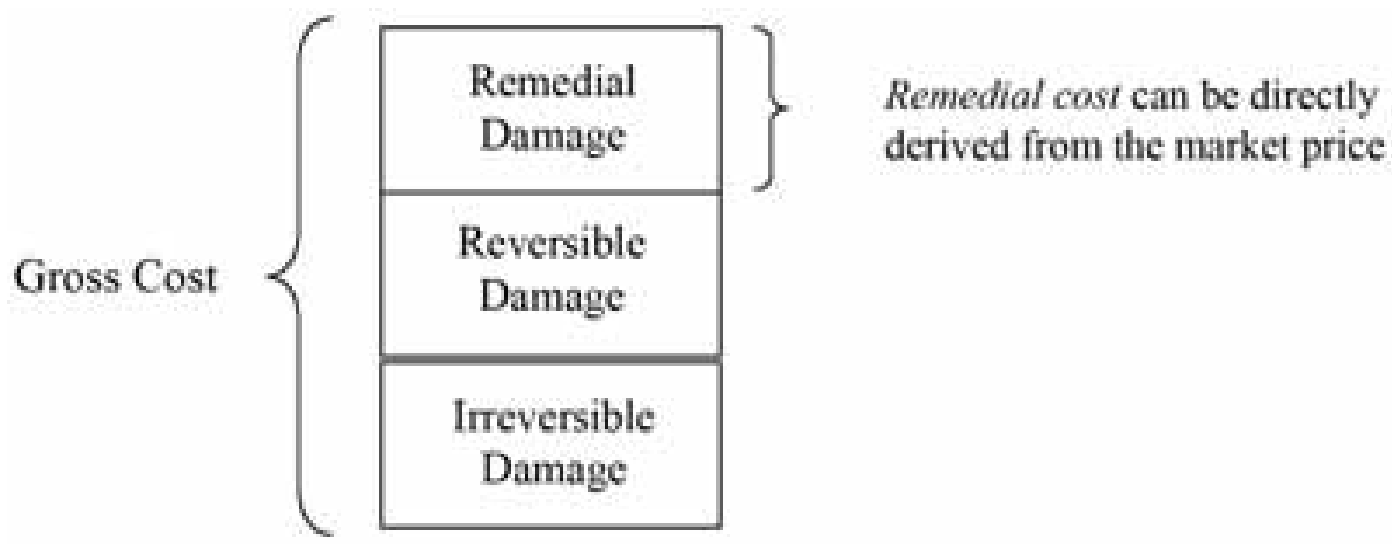

Figure 1. Three main components of gross environmental cost.

gauge the contribution of the environmental resource to the output derived from the use (direct or indirect) by those who rely on it for the production of goods or services" (Campbell and Brown 2003:269). The production approach is easy to understand and apply. Market data are usually available. In other words, this approach uses market prices to value nonmarket goods and services.

THE EXPENDITURE APPROACH. The expenditure approach uses market prices to esti- mate the costs of preventing, rehabilitating, and/or mitigating environmental damage. There are three main types of environmental damage. They are defined as remedial damage, reversible damage, and irreversible damage (Figure 1). One of the most important aspects of this economic valuation is the definition of cost.

When applied to loss of biodiversity, the cost that would be appropriate for economic valuation is called remedial cost. The reme- 
TABLE 2

Value of Fiji's Terrestrial Ecosystem Services

\begin{tabular}{llcc}
\hline \hline Ecosystem & \multicolumn{1}{c}{ Services Valued } & Unit Value (per ha/yr) & Total Value per Yr \\
\hline Mangroves and estuaries & Food production & F\$2,402 & F\$100.88 million \\
& Nutrient cycling & NA & \\
& Habitat & NA & \\
\multirow{3}{*}{ Tropical moist forest } & Disturbance regulation & F\$2,500 & F\$105 million \\
& Climate regulation & F\$323 & (F\$246 million) \\
& Water regulation and supply & F\$20.6 & F\$15.45 million \\
& Raw materials provision & F\$87.9 & F\$65.9 million \\
& Biodiversity preservation & F\$14.7 & F\$11.03 million \\
\hline
\end{tabular}

Note: Adapted from Sisto (1999).

dial cost is determined by the expenditure approach valuation method; however, loss of biodiversity involving extinction of species cannot be remedied.

the utility approach. Neoclassical economic theory assumes that consumers are rational and make consumption decisions in accordance with the objective of maximizing their individual utility, subject to their income or budget constraints, and given the prices of all goods and services. The utility approach therefore estimates value by trying to ascertain how much individual consumers of an ecosystem gain from their use or nonuse of the ecosystem. The concept that is used to describe this is "willingness to pay" (WTP).

\section{Previous Economic Valuation Study of Fiji's Ecosystems}

A study of selected Fijian ecosystems was conducted by Sisto (1999). The study was incorporated into Fiji's National Biodiversity Strategy Action Plan (BSAP). The method he used to derive the values for the tropical moist forest ecosystem was based on studies that were done in other places with similar socioeconomic and ecological attributes. Table 2 illustrates the economic value of two Fijian ecosystems.

Because of time constraints, a systematic valuation methodology was not developed during the formulation of the BSAP. The PABITRA project provides an ideal opportunity for the development of a systematic and adaptive valuation process.
QUALITATIVE APPROACH: PARTICIPATORY APPROACH TO VALUATION

For the Fiji PABITRA sites three nonmarket valuation approaches may be applied to value the various environmental goods and services provided by the ecosystems in the various sites.

Participatory economic valuation has emerged out of a dissatisfaction with neoclassical methods, which have failed to take into account equity, livelihood, and institutional issues (Richards and Davies 1999). The participatory approach has conceptual and practical advantages. Conceptually, the hidden nature of wild resources warrants an approach that emphasizes local-level knowledge and experience. Furthermore, certain participatory research tools, such as wealth ranking and seasonal calendars, are ideally suited to investigating the complex economic questions about differences in valuation among local users as well as seasonality or changes in value over time (Richards et al. 1999). Some studies have experimented with the use of participatory valuation methods such as ranking and scoring by local users and contingent ranking (Cannon 1998).

Participatory economic valuation has made an important contribution to the more qualitative aspects of economic valuation, but its potential for economic quantification remains uncertain and further research is required (Richards et al. 1999). However, the participatory approach should be seen as a complement rather than a substitute for conventional 
TABLE 3

Applications of Participatory Economic Valuation

\begin{tabular}{|c|c|c|}
\hline Question to Be Asked & Economic Perspective & Participatory Technique \\
\hline $\begin{array}{l}\text { 1. What resources are there } \\
\text { and where are they? }\end{array}$ & $\begin{array}{l}\text { - Inventory of resources in quantitative, } \\
\text { physical terms, differentiated by location }\end{array}$ & $\begin{array}{l}\text { - Participatory mapping } \\
\text { - Transects } \\
\text { - Mobility maps }\end{array}$ \\
\hline $\begin{array}{l}\text { 2. Why are they important } \\
\text { and what benefits do } \\
\text { they provide? }\end{array}$ & - Uses made of resources & $\begin{array}{l}\text { - Relative ranking } \\
\text { - Matrix scoring } \\
\text { - Role plays } \\
\text { - Pie diagrams }\end{array}$ \\
\hline $\begin{array}{l}\text { 3. When are they used } \\
\text { and/or available? }\end{array}$ & $\begin{array}{l}\text { - Months/seasons in which harvested } \\
\text { - Complementary with other economic } \\
\text { activities }\end{array}$ & $\begin{array}{l}\text { - Seasonal calendars } \\
\text { - Daily and seasonal labor and } \\
\text { activity calendars } \\
\text { - Product flow diagrams }\end{array}$ \\
\hline 4. Who uses them? & $\begin{array}{l}\text { - Which groups of individuals by gender } \\
\text { and household socioeconomic group }\end{array}$ & $\begin{array}{l}\text { - Well-being (wealth) ranking } \\
\text { - Social maps }\end{array}$ \\
\hline 5. How are they used? & $\begin{array}{l}\text { - What are the stages of harvesting, } \\
\text { processing, and selling? } \\
\text { - Who is involved in these? }\end{array}$ & $\begin{array}{l}\text { - Product flow diagrams } \\
\text { - Chain interviewing }\end{array}$ \\
\hline $\begin{array}{l}\text { 6. Who controls these } \\
\text { stages? }\end{array}$ & $\begin{array}{l}\text { - How many people or groups are } \\
\text { involved? } \\
\text { Do they exercise control (i.e., market } \\
\text { concentration)? } \\
\text { - What are the rules and rights governing } \\
\text { use and how do they translate into } \\
\text { practice? }\end{array}$ & $\begin{array}{l}\text { - Tenure/social maps } \\
\text { - Venn diagrams } \\
\text { - Network diagrams } \\
\text { - Case studies }\end{array}$ \\
\hline $\begin{array}{l}\text { 7. What are they worth in } \\
\text { monetary terms? }\end{array}$ & $\begin{array}{l}\text { What is the monetary value per time } \\
\text { period per harvester (by type) and } \\
\text { community? } \\
\text { What is the value of an equivalent } \\
\text { substitute or barter good? }\end{array}$ & $\begin{array}{l}\text { - Product story } \\
\text { - Product transect } \\
\text { - Substitute ranking }\end{array}$ \\
\hline $\begin{array}{l}\text { 8. What is the relative } \\
\text { importance of their } \\
\text { indirect use or nonuse } \\
\text { values? }\end{array}$ & $\begin{array}{l}\text { - How important are these values } \\
\text { compared with other tangible goods? } \\
\text { - What production activities depend on } \\
\text { their existence and to what extent? }\end{array}$ & $\begin{array}{l}\text { - Role plays } \\
\text { - Ranking and scoring matrices }\end{array}$ \\
\hline $\begin{array}{l}\text { 9. How sustainable is } \\
\text { resource use? }\end{array}$ & $\begin{array}{l}\text { - How are quantities changing over time? } \\
\text { - How do these compare with natural } \\
\text { productivity? }\end{array}$ & $\begin{array}{l}\text { - Historical maps, transects, } \\
\text { and matrices } \\
\text { - Trend ranking/analysis } \\
\text { - Critical events analysis }\end{array}$ \\
\hline
\end{tabular}

Note: Adapted from Richards and Davies (1999).

economic research methodologies. When the neoclassical approach is combined with participatory research methods, it is argued that both the quantitative and qualitative aspects of economic value are tackled. Richards and Davies' (1999) study revealed that it is possible to include participatory findings in conventional analyses as well. In other words, social and cultural activities, institutional (organizational, governance issues), livelihood (day-to-day, mundane activities), and equity issues can be incorporated into the valuation analysis (Table 3 ).
The participatory economic valuation approach has the following attributes: (1) it fully utilizes the data and knowledge of local decision makers and stakeholders, and maximizes the involvement and feedback from partners and counterparts to develop and improve the resource valuation analyses and approach; and (2) it raises awareness among all valuation participants of the need for economic valuation of resource use, the kind of information that valuation can provide, and the way in which valuation can be carried out. 


\section{Proposed Participatory Economic Valuation Steps}

The following participatory economic valuation steps provide an appropriate qualitative valuation framework that can be adapted and adopted in the Fiji PABITRA sites. The proposed participatory economic valuation steps have been adapted from the studies of Cameron (1997), Cannon (1998), Richards and Davies (1999), and Richards et al. (1999).

Step 1: Preliminary presentations to community leaders to explain the context and concept of resource valuation.

STEP 2: Collection of community data to feed into technical focus groups that consist of representatives from relevant government departments, business agencies (agriculturalor forestry-based businesses) and nongovernment (profit) organizations, and local communities.

STEP 3: Technical focus groups are formed that gather necessary data and information from the stakeholders assessing:

(a) the profits of their activities;

(b) the environmental conditions required by their activities, and how the profits of their activities may change in response to changes in these conditions;

(c) the physical changes (impacts) that result from their activities; and

(d) the distribution of the profits of their activities, and how this distribution might need to be altered.

STEP 4: Carry out a technical participatory valuation workshop for the technical focus groups. The assessments made in step 2 can be combined to determine the economic costs and benefits of the impacts of different activities as measured by changes in productivity or earnings in the other activities.

STEP 5: The results of the participatory valuation workshop can then be presented to: (1) community leaders and stakeholders, (2) local technical experts, and (3) senior decision makers.

STEP 6: The data and information gathered as part of the valuation exercise are used to assess stakeholder incentives and design cost-effective management policies and regulations that will deliver the desired land and resource use.

\section{CONCLUSIONS}

To have an effective applied and adaptive research component it is critical to apply both valuation approaches (the neoclassical and the participatory approaches) so that the various social, cultural, ecological, and economic values are harmonized in an economic valuation framework. This would provide qualitative and quantitative information that may assist decision makers and stakeholders at community and national levels in making wise decisions on the management and use of their biodiversity. It is the footstool for future integrated resource management and biodiversity conservation activities in Fiji's PABITRA sites.

\section{Literature Cited}

Barbier, E. B., A. Markandaya, and D. W. Pearce. 1998. Environmental sustainability and cost-benefit analysis. Environ. Planning 22:1259-1266.

Cameron, J. I. 1997. Applying socioecological economics: A case study of contingent valuation and integrated catchment management. Ecol. Econ. 23:155165.

Campbell, H. F., and R. P. C. Brown. 2003. Valuation of non-market goods. Pages 261-287 in H. F. Campbell and R. P. C. Brown, eds. Benefit-cost analysis: Financial and economic appraisal using spreadsheet. Cambridge University Press, Cambridge, U.K.

Cannon, J. 1998. Participatory Workshop for the Economic Valuation of Natural Resources in the Tongean Islands, Palu, Central Sulawesi. Natural Resource Management Programme/Environmental Policy and Institutional Strengthening Indefinite Quantity, Conservation International. U.S. Agency for International Development.

Gregersen, H., L. Arnold, A. Lundgren, and A. Contreras-Hermosilla. 1995. Valuing forests: Context, issues and guidelines. FAO Forestry Paper 127, Rome.

Moran, D., and D. Pearce. 1999. The economics of biodiversity. Pages 82-113 in 
H. Folmer and T. Tietenberg, eds. The international yearbook of environmental and resource economics 1997/1998: A survey of current issues. Edward Elgar Publishing, Ltd., Cheltenham, U.K.

Richards, M., and J. Davies. 1999. The use of economics to assess stakeholder incentives in participatory forest management: A review. European Union Tropical Forestry Paper 5. Overseas Development Institute, London.

Richards, M., K. Kanel, M. Maharjan, and J. Davies. 1999. Towards participatory economic analysis by forest user groups in Nepal. Overseas Development Institute in collaboration with the Nepal-U.K. Community Forestry Project, Department for International Development, U.K.

Sisto, N. P. 1999. An economic valuation of Fiji's major natural ecosystems. J. Pac. Stud. 23 (1): 71-90.

Tietenberg, T. 2000. Valuing the environment: Methods. Pages 34-60 in T. Tietenberg, ed. Environmental and natural resource economics. 5th ed. AddisonWesley Longman, Inc., Massachusetts. 
